\title{
Multimedia Development as Creativity in the Socialization of Covid19 Vaccination Against the Public
}

\author{
Dewi Irmawati ${ }^{1}$ Devi Sartika ${ }^{1}$ Ienda Meiriska ${ }^{1}$ Leni Novianti ${ }^{1, *}$ \\ ${ }^{1}$ Study Program of Informatics Management, State Polytechnic of Sriwijaya \\ *Corresponding author._Email: leni_novianti_mi@polsri.ac.id
}

\begin{abstract}
Cases of the Covid-19 virus have hit all over the world from Asia, Europe, America, Australia and Africa, so the World Health Organization (WHO) states that cases of Covid19 virus are not endemic but pandemics in the world because it has lasted almost 2 years after it began at the end of 2019 in Wuhan city of China. With an incubation period of 14 days, the Covid 19 virus can mutate so that its spread is still ongoing. The ability of the Covid-19 Virus to mutate resulted in the number of Covid-19 virus sufferers continues to increase. To prevent an increase in the spread of the Covid-19 virus, the Indonesian government has imposed Work From Home (WHF). Pembatasan Sosial Berskala Besar (PSBB) and apply the slogan 3M which is wearing a mask, washing hands and maintaining distance. In fact, on the ground, it still cannot suppress the spread of the Covid19 virus continues to increase. But now the Covid19 vaccine can help the prevention process in breaking the chain of this virus. To do the vaccination not a few people who do not want to be vaccinated because of the lack of knowledge about this vaccination itself and the benefits obtained after the Covid19 vaccination. For this reason, socialization is needed as a medium of information for the public to know the positive impact obtained after this vaccination. Socialization will be applied in the community by using multimedia technology, namely adobe photoshop software, Adobe After Effect, Adobe Illustrator. This animation uses the 4D development method (Define, Design, Development, and Dissemination). The output of this research is in the form of animation applications, ISSN National Journal, Video of the application. It is hoped that with the development of multimedia this can be one of the government's alternatives to socialize the benefits of Covid19 vaccination so that the cloud community knows and understands the Covid19 vaccination and the community without any coercion from the government, the community is willing and comes to participate in Covid19 vaccination activities in places that have been referred by the government for Covid19 vaccination.
\end{abstract}

Keywords: Covid-19, Animation, After Effect, 4D, Socialization.

\section{INTRODUCTION}

As of December 2019, there has been an increase in the number of cases of novel coronavirus pneumonia (NCP) in Wuhan, Hubei Province, China. Because of the spread of cases that are still active to the rest of the world, WHO named this case as Corona Virus Disease 2019 (COVID-19). The Chinese government has been taking action by passing a Law of the People's Republic of China (PRC) on Prevention and Action against Infectious Diseases, so that COVID-19 is categorized as a Class B Infectious Disease (communicable disenses) and then treated as a Class A Infectious Disease.

Coronavirus $(\mathrm{CoV})$ itself is a virus that causes diseases ranging from mild to severe symptoms. There are at least two types of coronavirus known to cause diseases that can cause severe symptoms such as Middle East Respiratory Syndrome (MERS-CoV) and Severe Acute Respiratory Syndrome (SARSCoV). Novel coronavirus (2019-nCoV) is a new type of virus that has never been identified in humans. Clinical manifestations usually appear within 2 to 14 days after exposure. Signs 
and symptoms of coronavirus are usually the appearance of symptoms of acute respiratory disorders such as cough, fever and shortness of breath. In severe cases it can cause pneumonia, kidney failure and at worst death. At the beginning of the appearance of this virus, X-rays showed widespread infiltration of pneumonia in both lungs. According to the results of the initial epidemiological investigation, most cases in Wuhan, have a history of working, handling and/or frequent visitors to the Seafood Wholesale Market in the Huanan area. Until now, the cause of transmission is still not known with certainty [1].

During this time to prevent COVID-19 is done by diagnosis with a PCR test(polymerase chain reaction)and swabs on respiratory tract fluid. And now there is a vaccine to help the prevention process to break the chain of this virus. But to do the vaccination not a few people who do not want to be vaccinated. This is based on a lack of knowledge regarding these vaccinations themselves. That's why we need a socialization as a medium information for the public to know the positive impact obtained after this vaccination. Therefore, we raised this issue as our research with the title"Application of Multimedia in the Socialization of COVID-19 Vaccination".

\section{DESCRIPTION OF STUDY AREA}

In providing information media for the public about the positive impact after vaccination is still fairly minimal. Due to lack of knowledge about the COVID19 vaccine.

On this occasion, the use of technology is expected as a facilitator that can provide information to the public about the positive impact after vaccination. Based on the above explanation it can be concluded that the problems that exist now, are:

1. Lack of knowledge about COVID-19 vaccination.

2. There is no information media for the public to know the positive impact after vaccination.

3. There is still little socialization to the field about good and correct prevention regarding COVID-19.

Therefore, to optimize in terms of socialization about COVID-19 vaccination, how to apply multimedia in the COVID-19 vaccination socialization process.

\subsection{Multimedia}

Multimedia is a field related to the integration of text, images, graphics, still and moving images designed and controlled using computers (animations), audio, and other media where in each type of information can be represented, stored, sent, and processed digitally [2].
Mulyana, et al, explained that the notion of multimedia is a medium of communication and information by combining text, graphics, video, and animation used to convey a particular message through computer media and other electronic equipment (VCD, projector, and video) [3].

Asmoro, mentions that multimedia is a combination of several elements namely text, graphics, sound, video, and animation that can produce amazing presentations [4].

\subsection{Socialization}

Socialization is a process of learning a member of the community to accept and adjust to the culture of the community in his environment [5].

Sulistyono, et al, explained that the understanding of socialization is the process to learn the patterns of people's lives that are adapted to the values, norms, and habits that apply to develop as members of society and individuals (individuals) [6].

Waluya, tells that the meaning of socialization is a way to instill the values and norms that exist in society to individuals by providing knowledge and family to individuals as a provision for community life to form members of society full of intact persons so that it is useful for themselves and society [7].

\section{DEVELOPMENT PROCEDURES}

\subsection{Stages of Problem Formulation}

This stage is the process of formulating problems and limiting the problems to be studied. This is needed in order to better direct researchers in making this socialization video so that what is done is not out of the limits that have been set before.

\subsection{Stages of Data Collection}

In the data collection stage, the author refers to suryabrata opinion, where the opinion describes the method of data collection that divides the method into two types [8], namely:

1. Primary data is the data first recorded and collected in a study. Primary data (primary data) requires direct interaction with students.

2. Secondary data is data collected from existing sources. Here, the author takes data indirectly by searching for and studying references to journals, books, articles, supporting theories and other references related to research. 


\subsection{Stages of Socialization Video Design}

Media development research as a medium of vaccination socialization by using this animated video to provide learning, and information media about covid-19 vaccination. Research and Development is a research method used to produce a particular product, and test the effectiveness of that product. Research and development aims to produce new products through the development process. Research products in the field can be models, media, equipment, books, evaluation tools and learning devices; Ulum, school policy and others.

One of the research and development models developed by Thiagarajan (1974) quoted in Endang Mulyantiningsih (2011: 179) is the 4D model(Define, Design, Development, and Dissemination) [9].

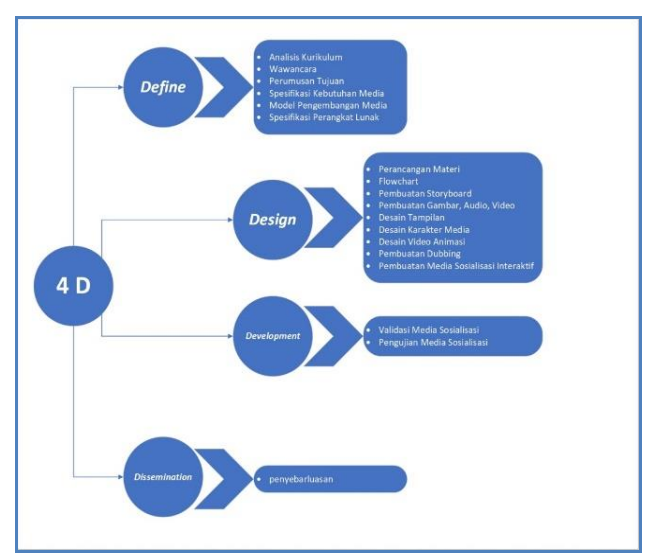

Figure 1 Scheme of Med Development Research Procedureshe

\section{RESULT AND DISCUSSION}

\subsection{Define Stages}

The define stage aims to define the terms of product development that are in accordance with the needs of the user. The define stage is carried out activities aimed at analyzing development needs, as well as defining product development requirements that are in accordance with user needs. Activities included in the define stage are curriculum analysis, interviews, goal formulation, media needs specifications, media development models and software specifications. This define stage can be various stages, namely: Curriculum Analysis, Interview, Preparing Materials, Goal Formulation, Media Needs Specification, Learning Media Development Model, Software Specification. The supporting components in making this video are:

1. Hardware :

\section{Laptop}

Operating System

Processor
: Dell Inspirion 15-5575

: Windows 1064 byte

:AMD Ryzen 5 2500, Radeon Vega Mobile Gfx
2. Software :

Adobe Photoshop CC 2017 :Used to create assets or images

Adobe Illustrator CC 2017

:Used to create assets or images in vector form

Adobe After Effect CC 2017 :Used to do editing motion graphics, transition effects and effects image effect.

Media Encoder CC 2017

\subsection{Design Stages}

:Used to render files From adobe after effect to video which can be watched in mp4 mpeg, dll.

At the design stage, we will make the initial product or product design which in this case is the design or creation of an animated video concept. Included in this stage are material design, flowchart creation, storyboarding, scripting, image or asset creation, animation process, background or background creation, music audio creation, and display design that will be used in animation creation.

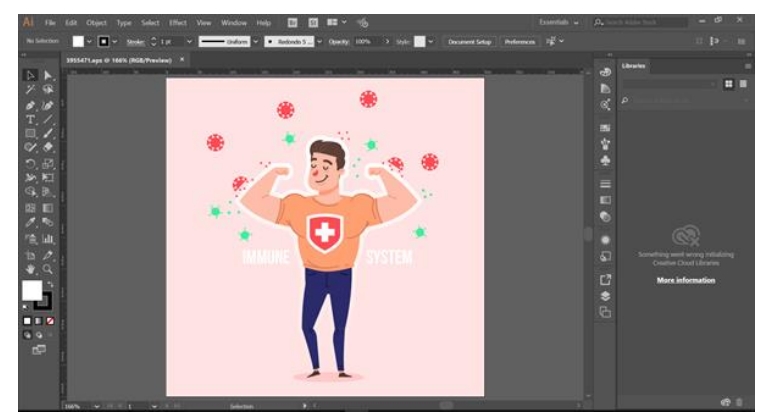

Figure 2 Video character creation

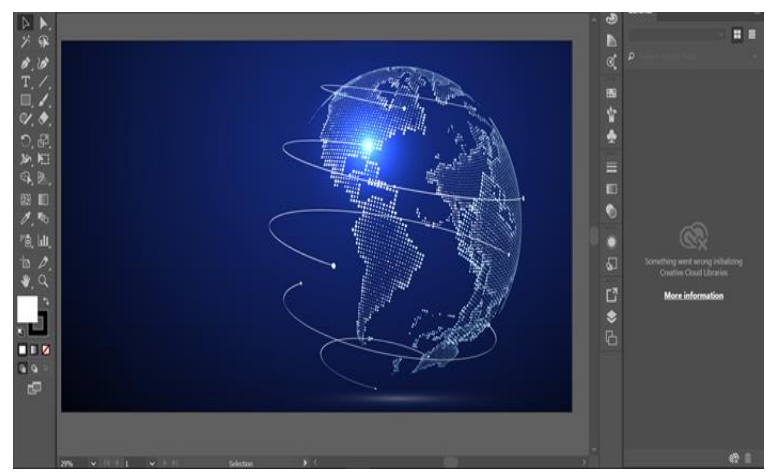

Figure 3 Video asset creation 


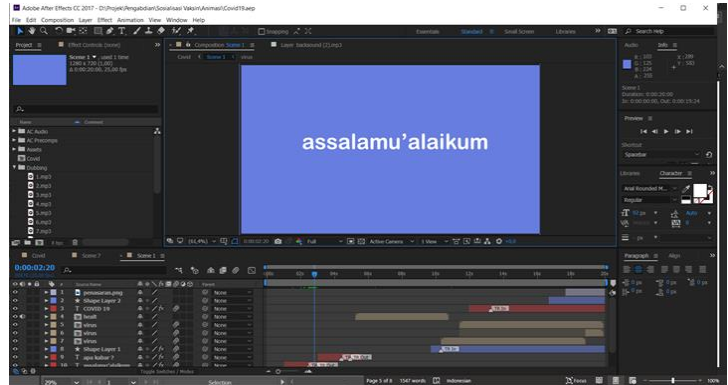

Figure 4 of the opening animation process

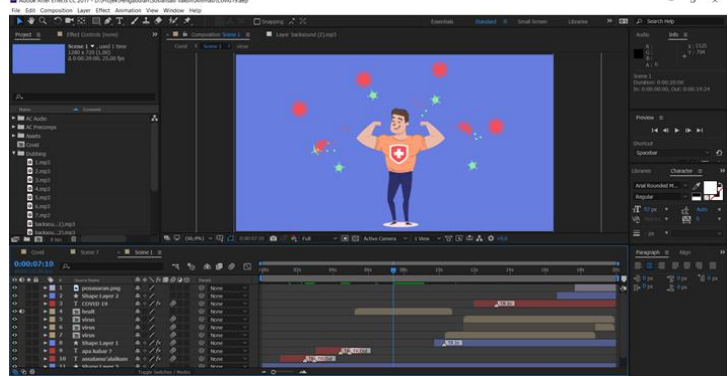

Figure 5 animation process scene 1

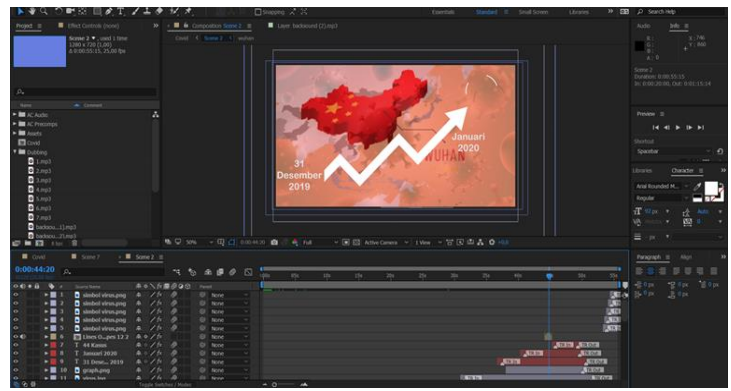

Figure 6 animation process scene 2

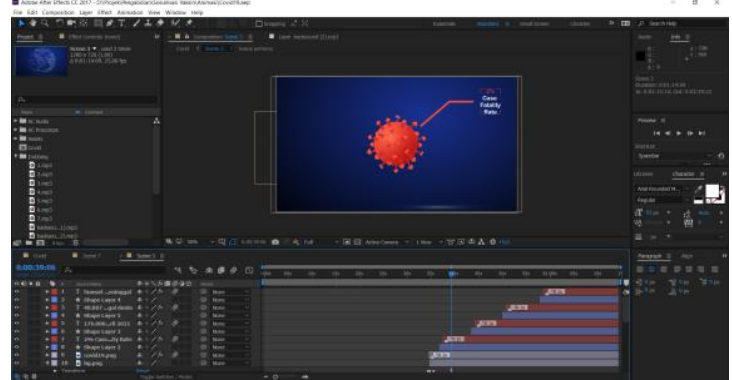

Figure 7 animation process scene 3

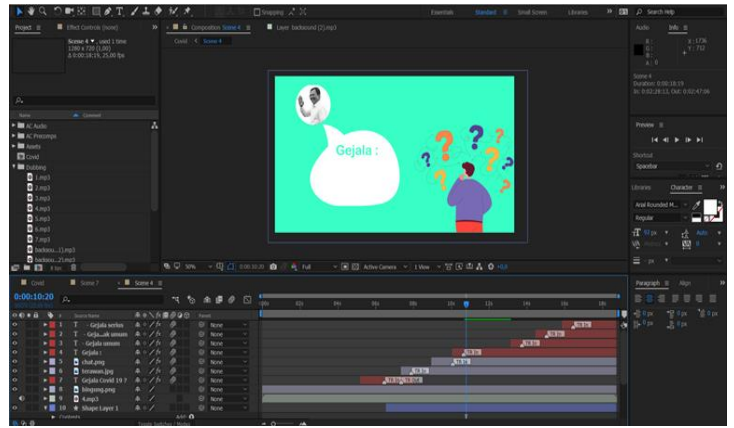

Figure 8 animation process scene 4

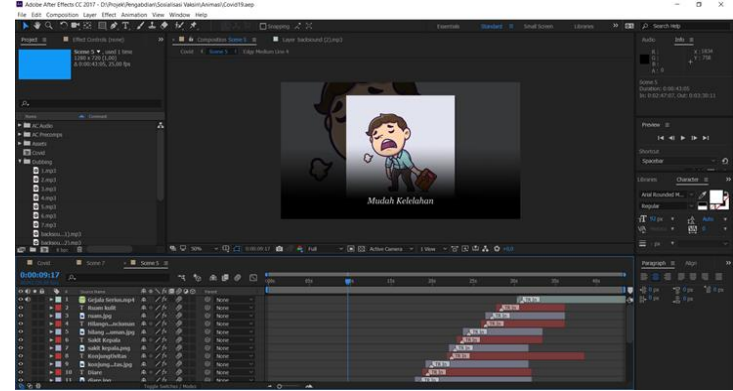

Figure 9 animation process scene 5

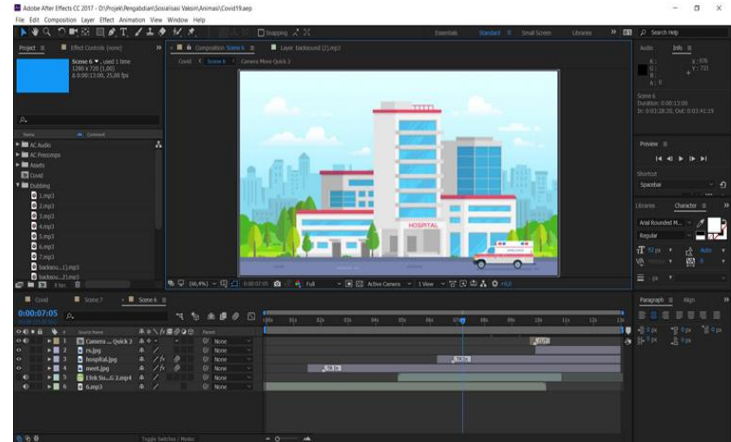

Figure 10 animation process scene 6

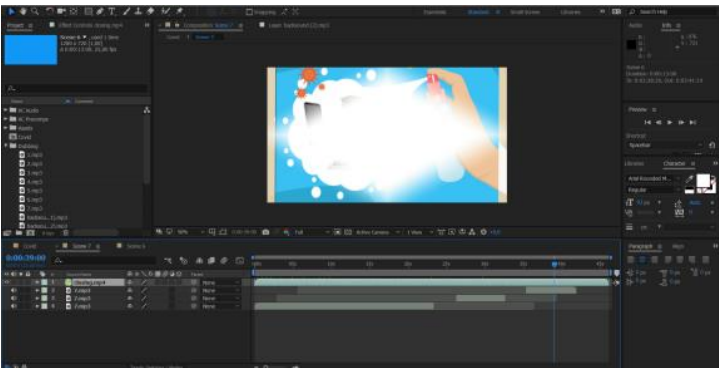

Figure 11 animation process scene 7

\subsection{Development Stages}

After doing the design or design stage, then the next step is to do development or it can also be adjusted as an implementation stage of the previously made design by referring to the concepts that have been made at the previous point. But there is something that is no less important in this development is the feasibility test on users. The feasibility test here is before the video is published we will conduct an interview or ask respondents for opinions about the video that has been made. This aims to find out the shortcomings contained in this socialization video. 
Table 1 Respond

\begin{tabular}{|c|c|c|c|}
\hline No & Name & Gender & $\begin{array}{l}\text { Respondent } \\
\text { Code }\end{array}$ \\
\hline 1 & Lara Okfa & Woman & R1 \\
\hline 2 & $\begin{array}{l}\text { Muhammad } \\
\text { Habiburrahman }\end{array}$ & Man & $\mathrm{R} 2$ \\
\hline 3 & Jack Harnes & Man & R3 \\
\hline 4 & $\begin{array}{l}\text { Rismal } \\
\text { Wahyudi }\end{array}$ & Man & $\mathrm{R} 4$ \\
\hline 5 & Three Seltawik & Woman & R5 \\
\hline 6 & Fuji Lestari & Woman & R6 \\
\hline 7 & Sodikin & Man & R7 \\
\hline 8 & Alfredo Julian & Man & $\mathrm{R} 8$ \\
\hline 9 & $\begin{array}{l}\text { Ricky } \\
\text { Juliansyah }\end{array}$ & Man & R9 \\
\hline 10 & Early Melani & Woman & $\mathrm{R} 10$ \\
\hline
\end{tabular}

Table 2 Analysis of Male Respondents

\begin{tabular}{|c|c|c|c|c|c|c|c|c|}
\hline \multirow{2}{*}{$\begin{array}{r}\mathbf{N} \\
\mathbf{0}\end{array}$} & \multirow[b]{2}{*}{ Question } & \multicolumn{7}{|c|}{ Respondents (range 1-4) } \\
\hline & & $\begin{array}{l}\mathbf{R} \\
\mathbf{2}\end{array}$ & $\begin{array}{l}\mathbf{R} \\
\mathbf{3}\end{array}$ & $\begin{array}{l}R \\
4\end{array}$ & $\begin{array}{l}\mathbf{R} \\
7\end{array}$ & $\begin{array}{l}\mathbf{R} \\
\mathbf{8}\end{array}$ & $\begin{array}{l}\mathbf{R} \\
\mathbf{9}\end{array}$ & $\begin{array}{c}\text { Averag } \\
\text { e }\end{array}$ \\
\hline 1 & $\begin{array}{l}\text { Is information } \\
\text { easy to } \\
\text { understand? }\end{array}$ & 3 & 4 & 4 & 3 & 3 & 4 & 3,5 \\
\hline 2 & $\begin{array}{l}\text { Does the } \\
\text { information fit } \\
\text { the theme? }\end{array}$ & 4 & 4 & 4 & 4 & 4 & 4 & 4 \\
\hline 3 & $\begin{array}{l}\text { Interested in } \\
\text { video? }\end{array}$ & 4 & 4 & 3 & 3 & 4 & 3 & 3,5 \\
\hline 4 & $\begin{array}{l}\text { Visual and } \\
\text { sound } \\
\text { synchronizatio } \\
\mathrm{n} \text { ? }\end{array}$ & 4 & 4 & 4 & 4 & 4 & 4 & 4 \\
\hline 5 & $\begin{array}{l}\text { Clarity of } \\
\text { voice/dubbing? }\end{array}$ & 4 & 4 & 4 & 4 & 4 & 4 & 4 \\
\hline 6 & $\begin{array}{l}\text { Image/asset } \\
\text { clarity }\end{array}$ & 4 & 4 & 3 & 3 & 3 & 3 & 3,3 \\
\hline 7 & $\begin{array}{l}\text { Is the video on } \\
\text { target? }\end{array}$ & 4 & 4 & 4 & 4 & 4 & 4 & 4 \\
\hline
\end{tabular}

Table 3 Analysis of Female Respondents

\begin{tabular}{|c|l|c|c|c|c|c|}
\hline & \multicolumn{5}{|c|}{ Respondents (range 1-4) } \\
\hline $\mathbf{1}$ & \multicolumn{1}{|c|}{ Question } & $\begin{array}{l}\text { Is information } \\
\text { easy to }\end{array}$ & R5 & R6 & R10 & Average \\
\hline $\mathbf{2}$ & $\begin{array}{l}\text { understand? } \\
\text { Does the } \\
\text { information fit } \\
\text { the theme? }\end{array}$ & 4 & 4 & 4 & 3 & 3,5 \\
\hline $\mathbf{3}$ & $\begin{array}{l}\text { Interested in } \\
\text { video? }\end{array}$ & 4 & 3 & 3 & 3 & 3,25 \\
\hline $\mathbf{4}$ & $\begin{array}{l}\text { Visual and } \\
\text { sound }\end{array}$ & 4 & 4 & 4 & 3 & 3,75 \\
\hline $\mathbf{5}$ & $\begin{array}{l}\text { synchronization? } \\
\text { Clarity of } \\
\text { voice/dubbing? }\end{array}$ & 4 & 4 & 4 & 4 & 4 \\
\hline $\mathbf{6}$ & $\begin{array}{l}\text { Image/asset } \\
\text { clarity }\end{array}$ & 4 & 4 & 3 & 3 & 3,5 \\
\hline $\mathbf{7}$ & $\begin{array}{l}\text { Is the video on } \\
\text { target? }\end{array}$ & 4 & 4 & 4 & 4 & 4 \\
\hline
\end{tabular}

\subsection{Stages of Dessemination}

At this stage is the final stage of making a socialization video. The stage of dissemination or it can also be called the publication stage, where this stage of publication will be carried out to the general public when all previous processes have been implemented.

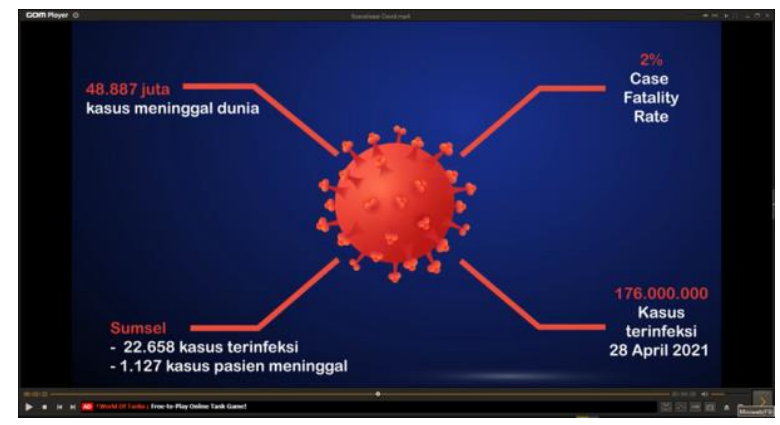

Figure 12 videos of redering results (publication)

\section{CONCLUSION}

Socialization will be applied in the community by using multimedia technology, namely adobe photoshop software, Adobe After Effect, Adobe Illustrator. This animation uses the 4D development method (Define, Design, Development, and Dissemination). The output of this research is in the form of animation applications, ISSN National Journal, Video of the application. It is hoped that with the development of multimedia this can be one of the government's alternatives to socialize the benefits of Covid19 vaccination so that the cloud community knows and understands the Covid19 vaccination and the community without any coercion from the government, the community is willing and comes to participate in Covid19 vaccination activities in places that have been referred by the government for Covid19 vaccination.

\section{REFERENCES}

[1] Directorate General of Disease Control and Control, Novel Coronavirus (2019-nCoV), Situation Report, 2020.

[2] Limbong, Tonni, dan Simarmata, Janner, 2020, Media dan Multimedia Pembelajaran : Teori \&Praktik, Medan: Yayasan Kita Menulis.

[3] Mulyana, dkk. 2019. Buku Ajar Desain Grafis dan Multimedia Teori dan Implementasi. Bogor: Lembaga Penelitian dan Pengabdian Masyarakat Universitas Pakuan

[4] W.S.Asmoro, 2019. Teknik Pengolahan Audio dan Vidio. Malang: Bumi Aksara. 
[5] J. Untoro et al, 2010, Buku Pintar Pelajaran: Rumus Materi Lengkap dan Kumpulan Rumus Lengkap. Jakarta: Wahyu Media

[6] Adi Sulistiyono dan Isharyanto, Sistem Peradilan di Indonesia Dalam Teori dan Praktik, Depok: Prenamedia Group, 2018.
[7] Waluya, Bagja. 2007, Sosiologi : Menyelami Fenomena Sosial di Masyarakat, Bandung : PT. Setia Purna Inves.

[8] Suryabrata,Sumadi. (2016). Metodologi Penelitian. Jakarta: PT Raja Drafindo Persada

[9] Mulyatiningsih, E. 2011. Metode Penelitian Terapan Bidang Pendidikan. Yogyakarta: Alfabeta. 